\title{
Reflections on the Scientific Conceptual Streams in Leonardo da Vinci and His Relationship with Luca Pacioli
}

\author{
Raffaele Pisano \\ Centre Sciences, Sociétés, Cultures dans leurs Evolutions, University of Lille 1, Lille, France \\ Email: pisanoraffaele@iol.it
}

Received March $19^{\text {th }}, 2013$; revised April $25^{\text {th }}, 2013$; accepted May $2^{\text {nd }}, 2013$

\begin{abstract}
Copyright (C) 2013 Raffaele Pisano. This is an open access article distributed under the Creative Commons Attribution License, which permits unrestricted use, distribution, and reproduction in any medium, provided the original work is properly cited.
\end{abstract}

\begin{abstract}
Leonardo da Vinci (1452-1519) is perhaps overrated for his contributions to physical science, since his technical approach. Nevertheless important components concerning practical problems of mechanics with great technical ability were abounded. He brought alive again the Nemorarius' (fl. 12th - 13th century) tradition and his speculations on mechanics, if immature made known how difficult and elusive were the conceptual streams of the foundations of science for practitioners-artisans. Leonardo also had an interesting and intense relationship with mathematics but merely unhappy insights in his time. The meeting with Luca Bartolomeo de Pacioli (1445-1517) was very important for da Vinci since proposing stimulating speculations were implemented, but they were not definitive theoretical results. In this paper historical reflections notes on mechanics and mathematics in da Vinci and his relationships with Pacioli are presented.
\end{abstract}

Keywords: Scientia de Ponderibus; Mathematical Renaissance; da Vinci; Pacioli; Mechanics

\section{An Outline}

The emergence of the figure of the engineer seen as a technician in some way educated in sciences, is a characteristic feature of the XV century and the first half of the XVI. Indeed this is perhaps the main feature of science, where the reduced creativity (real or apparent) of pure scientists, was counterbalanced by the great creativity of applied scientists. A short list is sufficient to give an idea of the dimension of the phenomenon: Mariano di Jacopo called Taccola (1381-1458), Leon Battista Alberti (1404-1472), Francesco di Giorgio Martini (1439-1501), Leonardo da Vinci, Vannuccio Biringuccio (1480-1539), Francesco de' Marchi (1504-1576), Giovanni Battista Bellucci (15061554), Daniele Barbaro (1513-1570). Although there were no public funding to encourage scientists to devote their efforts to the study of technical applications and to the improvement of their knowledge, a common ground arose, particularly in Central and Northern Italy. The link between engineers and scientists emerged, at least in part, through the creation of some technical centres in the courts of the principalities which had been set up. This was the case of Medici's court in Florence, but also, and perhaps more importantly, the court of Milan under Francesco Sforza with its very rich library. Particularly in Urbino, Francesco di Giorgio Martini (1480-1490) wrote a translation of Vitruvius (see book X on machines) into Italian, questionable from a philological standpoint and Piero della Francesca (1415-1492) one of the greatest mathematicians and painters of the time, should be reported (Pisano, 2007, 2009; Pisano \& Capecchi, 2008, 2009, 2010a, 2010b, 2012).

Leonardo introduced the concept of pratica (Gille; Sarton) as the basis of any of his studies, defining it either as observation, a study of buildings, of human anatomy and natural phenomena, or as an experiment aimed at checking up the calculations derived from his observation. On the other hand, he defines himself discepolo della sperienza. To him, from experience we can derive, beyond good building practices, also rules that are not only the expression of aesthetic research but principally requirements for the proper performance of the building organism, considered at the same time as a living organism or a macchina-ingegno. He is an artist but also a technician and a scholar and it would be a mistake, assuming a position systematically too antithetic to the official thesis, to assimilate his notes to a definitive work of art. Then, we must say that an indirect continuity in a bend toward science shown by Leonardo emerges when considering that the themes he dealt with had already been studied in early 1400 by Taccola who was interested in the scripts of mechanics and military technology of Pneumatica by Philon of Byzantium (280-220 B.C.). As the majority of engineers by that time, Leonardo also studied the engineering works by Heron from Alexandria (fl. I-II? B.C.) though considered useless toys (Heron, 1575, 1893, 1900, 1999). On the other hand, they got enthusiastic before the futuristic technical designs by Leonardo in that when not copying it, they were strongly influenced by them, such as Hero's engine, windwheel, vending machine, force pump, Heron's fountain et al. Gille ends up his book with a hope:

All our engineers were men of war. [...]. But the enquiry remains open: it might bring to light other works still languishing in the dust of libraries, it might also provide a 


\section{R. PISANO}

more precise analysis of the notebooks which have never been published and which are full of information ${ }^{1}$.

In spite of because no Greek and Latin knowledge he learnt, it is reasonable to think that he had no direct access to classical ancient works; on that he wrote interesting annotations in the Codex Atlantico and Codex Leicester (ex Codex Hammer). On his classical language education he wrote:

I know very well that because I am unlettered some presumptuous people will think they have the right to criticize me, saying that I am an uncultured man. What unintelligent fools ${ }^{2}$ !

\section{Introduction}

The privileged geographical position of Italy in the Mediterranean caused interesting commercial exchanges with Africa and the Middle East that favoured the free circulation and the widespread of Greek works throughout Italy and Northern Europe. On the other hand, when the Turks captured Constantinople (1453) many Greek scholars moved to Europe (several of them to Italy as well), taking with them important manuscripts and making the knowledge of the classical culture more accessible, compared with the past 12 th and 13 th centuries. The translation into Latin straight from the Greek language made their contents more reliable. Reliability increased thanks to the invention of movable type printing (ca. 1450) by Johann Gutenberg (1400?-1467?). Approximately, since 1474 they started to print works of mathematics, astronomy and astrology in Italy. The edition ${ }^{3}$ (Elementa geometriae) by Giovanni Campano di Novara (1220-1296) might have been one of the first translations of the Elements by Euclid (fl $300 \mathrm{BC}$ ) in its Latin version (Knorr, 1978-1979, 1985; Busard, 2005). It included speeches from Arithmetica by Jordanus de Nemore, commentary on Euclid by Anaritius (865-922) and several additions by Campano, too. In such a climate and until Renaissance the image of the new scientist, seen also as a student of natural phenomena, emerged. He was seen as a new type of scientist, re-born and re-qualified, not just an interested and clever astrologer and medieval theologian. Above all he looked now independent from a hypothetical and general pre-established design. However, the reconcilement between the divine plan and the new mathematical truths could converge into an outlined project, still divine under many aspects, considering God as the engineer who had planned a cosmological design in mathematical and geometrical terms. God as an engineer allowed a certain chance of studying the divine product that is nature interpreted in mathematical terms, since in this way the object of study was still confined to a religious matter. In fact, this would explain why, among other things, the majority of the Renaissance scientists were theologians as well (of course not usually theologians in the sense of their principal employment) who preferred to inquire into nature instead of the Holy Scriptures. Therefore each discovery or mathematical invention was seen as the product of God's engineering work ${ }^{4}$. Though this new way of conceiving it science was limited to the learned and

\footnotetext{
${ }^{1}$ Gille, p 240; see also: Hall, 1997.

${ }^{2}$ da Vinci, Codex Atlanticus, f. 119v.

${ }^{3}$ Maybe made by Abelard of Bath (12th century) and annotated and edited by Campano. The edition in fifteen books, Preclarissimus liber elementorum Euclidis perspicacissimi [...] will published by Erhard Ratdolt in Venezia (1482). It is based on an Arabic translation from original Greek manuscript.
}

the rich only, since they had a knowledge of Latin and Greek. The spread of the new culture by print was hampered by two factors. First, a lot of technicians, such as architects and engineers, would have probably welcomed the application of geometry and mathematics as theoretical science to arts, navigation and architecture but the precarious diffusion of school education did not give the pioneers of scientia activa access to the necessary scientific heritage. Thus, according to some thought currents of history of mathematics, the expectation about the spread of the classical culture, instead of encouraging the highest erudition among mathematicians and, in general, of scientific topics, paradoxically seemed to exclude just the newborn class of scientists-mechanics who, far more numerous than theoretical scientists, felt a strong interest in the introduction of mechanical devices or of calculating ones within their treatises. Secondly, theoretical knowledge was the only one to be considered full and definitive, therefore experience was meant to be of secondary use, so the discoveries of technicians were ignored, eventually causing a strange regression toward the medieval culture typical of the Scholastics of 12th century. In particular, due to the lack of mathematical devices, technicians would feed their knowledge through the development of socalled procedures by comparison. Modelling by similitude were typical, after daily practice and based upon make mistakes and correct, almost to represent a sort of a practical, e.g., handbook of architecture. The scientific applications will flow into the new technology and will require more and more the integration of local activities and the managing skill of the artisans. This integration and the new reference to the Euclidean geometry will bring together with other physical-mathematical factorsthat will be the case study of the present thesis - to the realization of the first projects, after the aestimatio modelling, that is approximated and designed on the spot.

Mostly, at the end of the Middle Age mathematics was taught essentially at universities and at abacus schools. In the university, mathematics was taught in the quadrivium (arithmetic, geometry, astronomy and music) of the faculties of arts, that while maintaining their autonomy, were instrumental to the training of future physicians and theologians (Duhem, 1988: X; Grant, 2001; De Ridder-Symoens, 2003; Grendler, 2002). The medical faculties of the early Renaissance were usually those in which mathematics had more space. Medicine was, in fact, connected to the study of astrology, which required the students to have rudiments of Ptolemaic astronomy and then knowledge of elements of geometry and arithmetic. Professors of these subjects were the masters of liberal arts of the quadrivium, whose teaching and research many of the mathematical works of the XV century are connected. However the place occupied by mathematics was still marginal and also the level of mathematical knowledge, which except for some teachers was limited to what was indispensable for the exercise of astrology. In fact it did not cover the study of so many Greek classics that at the time were already available in Latin translations from Arabic of the XII century.

During the 16th -17 th centuries mechanics was a theoretical science and it was mathematical, although its object had a physical nature and had social utility. Texts in the Latin and Arabic Middle Ages diverted from the Greek. In particular alFarabi (ca. 870-950) differentiates between mechanics in the

${ }^{4}$ Of course one should also take into account Liber naturae (for ex: Numbers, 2006; Harrison, 1955; Vanderputten, 2005; Ophuijsen, 2005; Kusukawa, 2012; Jesseph, 2004; Pedersen, 1992; Biagioli, 2003; Marcacci, 2009). 
science of weights and that in the science of devices. On the other hand, the science of weights refers to the movement and equilibrium of weights suspended from a balance and aims to formulate principles. The science of devices refers to applications of mathematics to practical use and to machine construction. In the Latin world a process similar to that registered in the Arabic world occurred. Even here a science of movement of weights was constituted, namely Scientia de ponderibus. Besides this there was a branch of learning called mechanics, sometimes considered an activity of craftsmen, other times of engineers (Scientia de ingeniis).

\section{On the Scientia de Ponderibus}

The scientia de ponderibus saw the birth in the Arabic land (Capecchi, 2012, 2011). The status of a distinct Scientia to the science of weights first appeared in al-Farabi's (ca. 870-950) Ihșā' al-'ulüm (Enumeration of the sciences). In particular he definitely distinguished between science of weights and sciences of devices or machines. Al-Farabi (Schneider 2011) took six distinct sciences: language, logic, mathematics, nature, metaphysics and politics. The mathematics was divided into seven topics: arithmetic, geometry, perspective, music, science of weights and sciences of machines (Capecchi \& Pisano 2013) or devices:

As for the science of weights [emphasis added], it deals with the matters of weights from two standpoints: either by examining weights as much as they are measured or are of use to measure, and this is the investigation of the matters of the doctrine of balances (umūr al-qawl fi 1-mawāzīn), or by examining weights as much as they move or are of use to move, and this is the investigation of the principles of instruments (ușūl al-ālāt) by which heavy things are lifted and carried from one place to another.

As for the science of devices [emphasis added], it is the knowledge of the procedures by which one applies to natural bodies all that was proven to exist in the mathematical sciences... in statements and proofs into the natural bodies, and [the act at] locating [all that], and establishing it in actuality. The sciences of devices are therefore those that supply the knowledge of the methods and the procedures by which one can contrive to find this applicability and to demonstrate it in actuality in the natural bodies that are perceptible to the senses ${ }^{5}$.

The Scientia de ponderibus was different from Greek mechanics (Clagett and Moody [1952] 1960); Brown 1967-1968) both for the scope-Greek mechanics placed transportation of weights, instead of their equilibrium, at the centre - and for the methodology - the Scientia de ponderibus charged only of the theoretical foundations of equilibrium and not applicative aspects (Capecchi \& Pisano, 2013; Pisano, 2013). The Scientia de ponderibus was also different from the mechanics of the early XVI, the centrobaric, a discipline developed in the wake of the rediscovery of Archimedes (fl. 287-212 B.C.) which was concerned mainly with the mathematical problems of determining

${ }^{5}$ Othman, 1949: pp. 88-89. Interesting correlated comments are in Abattouy 2006, p. 12. See also Schneider, 2011; Abattouy, Renn, \& Weinig, 2001. In the secondary literature one can also see the science of weights proposed as science of balances and science of weight lifting: Ibn Sina (980-1037), al-Isfizārī (1048-1116), al-Khāzin̄i (1115-1130). the geometric centres of gravity of plane figures and solids (Ivi).

The new science of weights was characterized by a strong deductive system, in which components of qualitative and ideas in physics (Locqueneux) were formulated more geometrico. The most common historical point of view is that the science of weights originated from interplay of Aristotelian physics and the physical-mathematical theories of Archimedes and probably Euclid (Renn), on the equilibrium of bodies (Archimedes, 2002; Clagett, 1964-1984; Tartaglia, 1565a; Dijksterhuis, 1957).

From a methodological point of view the majority of treatises in the science of weights followed what is often called dynamical or more properly kinematical approach, in which the equilibrium is seen as a balance of opposing forces and the movement, virtual or real, has an important role. In these treatments the Aristotelian dichotomy, but not only, between the natural and forced, upward and downward, motions, disappears for they are considered on the balance, in which the weight is also the natural cause of lifting other weights. The geometrical approach, like the one carried out by Archimedes, is certainly uncommon, so that some historians does not even consider it as part of the science of weights.

In the Latin Middle Ages various treatises on the scientia de ponderibus circulated (Clagett 1959), as already mentioned in the introduction of this work. Among them, the most important are the treatises attributed to Elementa Jordani super demonstratione ponderum (version E), Liber Jordani de ponderibus (cum commento) (version (P), Liber Jordani de Nemore de ratione ponderis (version $\mathrm{R}$ ) (Capecchi \& Pisano, 2013). They were the object of comments up to the 16 century. It is not well known the distribution of the original manuscript; what is sure is that Liber Jordani de Nemore de ratione ponderis (version R) finished in Tartaglia's hands and was published posthumous in 1565 by Curtio Troiano as Iordani opvsculum de ponderositate (Tartaglia, 1565b; see also Tartaglia, 1554).

Generally, when the so-called scientia pratica of the Renaissance is referred to, we are reminded of engineers and, consequently, of Leonardo da Vinci, the great scholar who sums up a multiplicity of competences that nowadays would be considered as different crafts: from the engineer, architect, scientist to the artist (Pisano, 2007, 2009). Although some studies, such as from Pierre Duhem (1861-1916), Roberto Marcolongo (18621943), Clifford Truesdell (1919-2000) and Bertrand Gille (19201980) suggest a review of Leonardo da Vinci's role as a genius, in favour of a more human figure of a learned man, endowed with a quick intelligence, e.g. not all his designs about machines sprang out straight of his vision (Marcolongo, 1932; Truesdell; Gille).

The XV century records a check on the growth in the development of science and the publication of scientific papers. The check existed of course for the science of weights, too. In this case it also depended on the fact that the discipline, formulated axiomatically had reached its complete internal maturity and only the proposition of new problems would have lead to an evolution. Although until the early years of the XVI century no new major scientific treatise was written ${ }^{6}$, except the Summa de arithmetica, geometria, proportioni et proportionalità ${ }^{7}$ (hereafter Summa, Pacioli, 1494) and De divina proportione (Pacioli, 1509) by Luca Pacioli, it must be said that in this period the

\footnotetext{
${ }^{6}$ One can also see Questiones super tractatum de ponderibus (Pellicani) by Biagio Pellicani of Parma (d. 1416).

${ }^{7}$ The Summa was a teaching textbook mainly concerning general algebra.
} 
foundations of a major renovation were laid down, with the breaking of the spirit of the scholasticism system and the repudiation of the principle of authority, particularly that of Aristotle (384-322 B.C.), the rediscovery of Plato (427-347 B.C.) and Pythagoras (570-495 B.C.) and the valorization of mathematics which was the premise for the new philosophy of nature of the second half of the XVI century (Pisano, 2011).

\section{On Leonardo's Approach to Mechanical Science}

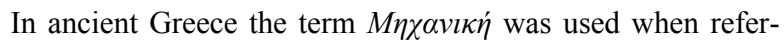
ring to machines and devices in general. To be more exact, it was intended to mean the study of simple machines (winch, lever, pulley, wedge, screw and inclined plane) with reference to motive powers and displacements of bodies (Capecchi \& Pisano, 2008, 2010a, 2010b). Historically works considering these arguments were referred to as Mechanics, from Aristotle, Heron, Pappus Alexandrinus (290-350 A.C.) to Galileo (15641642). None of the treatises entitled Mechanics avoided theoretical considerations on its object, particularly on the lever law. Moreover, there were treatises which exhausted their role in proving this law; important among them are The Euclid book on the balance by Euclid and On the Equilibrium of Planes by Archimedes (Archimedes, 2002). The Greek conception of mechanics is revived in the Renaissance, with a synthesis of Archimedean and Aristotelian routes. This is best represented by Mechanicorum liber by Guidobaldo dal Monte (1545-1607) who reconsiders Mechanics by Pappus (Pappus, 1588, 1970) maintaining that the original purpose was to reduce simple machines to the lever (dal Monte, 1581, 1588).

With the Renaissance in the XV century the medieval mathematics is joined by the new mathematics, or rather the rediscovered ancient Greek mathematics to which the humanist movement gave a great contribution. The essential role of Italian humanism in the renaissance of mathematics during the XV and XVI centuries was well documented in (Rose, 1975). Many humanists returned from their travels to Byzantium with codes of Apollonius (262-190 A.C.), Ptolemy (90-168 A.C.) Pappus, Heron written in Greek. In the early XVI century, within a few decades, many revisions and translations of classics were delivered, i.e., including the De expetendis et fugiendis rebus (1501) by Giorgio Valla, sort of rich encyclopaedic anthology of Greek scientific texts ${ }^{8}$ where

$[\ldots]$ the starting point for this renaissance of mathematics was the correction of Greek mathematical texts, to be undertaken by those who were expert in both the Greek language and astronomy. To make the refurbished traditions of Greek mathematics available to mathematicians generally, Regiomontanus from at least 1461 was engaged on a series of Latin translations. But by 1471 , this means of communication was revolutionised by Regiomontanus' discovery of the new invention of printing. Through printing, an astonishingly rapid and accurate dissemination of texts and translations become possible that had been inconceivable in an age where manuscripts represented the sole means of circulating the written word. In its fusion of mathematics, Greek and printing Regiomontanus' publishing Programme of 1474 marks the formal beginning of

${ }^{8}$ De rebus expetendis et fugiendis consisted of 49 books, 30 on sciences. Valla's book also contains interesting notes on Archimedes' works. the renaissance of mathematics 9 .

It should however be said that the reacquisition of mathematical techniques was rather slow. The humanist thought carried on meta-mathematical character concerned a new role that mathematics acquired within the philosophy of the Platonic and Pythagorean instances. On that the role played by Pacioli, which was in the same time teacher of abacus and magister theologiae, was crucial. This job allowed him to mediate the culture of technicians and learned men. Nevertheless the biblical metaphysical idea inspiring frà Luca Pacioli in his dedicatory letter "[...] Fratris Luca de Burgo Sancti Sepulcri, ordinis minorum, sacre theologiae Magistri [...]" (Pacioli, Summa, f. 3r) to Guidobaldo da Montefeltro (1472-1508) as "Ad Illustrissimum principem sui Ubaldum Duces Montis Feretri, Mathematice discipline cultorem serventissimum [...]" (Ibidem) was that the book of nature (later on resumed by Galileo ${ }^{10}$, too) is written in mathematical characters:

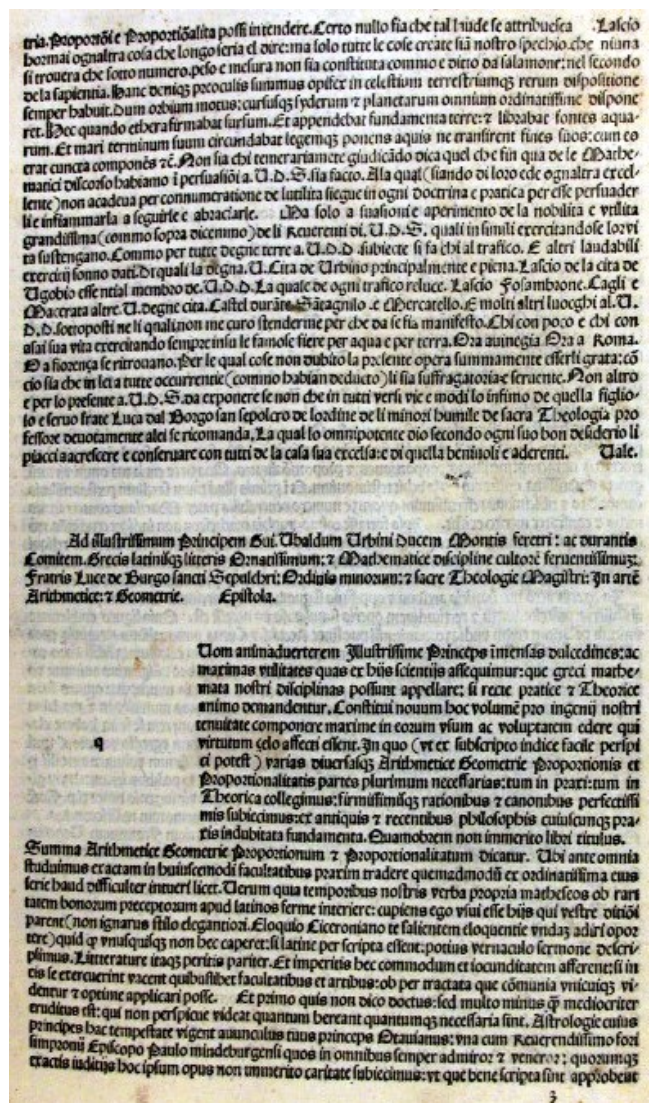

Let all create beings be our mirror, as no one will found to be constituted but as number, weight and measure, as said by Salomon in the second book of the Sapientia ${ }^{11}$.

\section{Figure 1.}

Plate from the initial part of the dedicatory letter by Pacioli (Pacioli, Summa, f. 3r) ${ }^{12}$.

\footnotetext{
${ }^{9}$ Rose, 1975 , p. 110.

${ }^{10}$ Galileo, 1890-1909. See also: Galluzzi \& Torrini, 1975-1984; Pisano, 2009d; Pisano \& Bussotti, 2012; Marcacci, 2009.

${ }^{11}$ Pacioli, 1494, Summa, f. 4r. Evidently, he alludes to the biblical text around I century BC.

${ }^{12}$ Source: Max Planck Institute for the History of science-Echo/Archimedes Project [via http://echo.mpiwg-berlin.mpg.de/content/historymechanics/ archimdesecho/archimedes-intro].
} 
It is evident from the large production of the secondary literature with respect since his was more the mentality of the engineer. Leonardo's notebooks are not organized and minor eloquent ${ }^{13}$ of the others authors at his time. He was a brilliant scholar, very intelligent and a great worker. His questionable assumptions on mechanics make known how complex, hard and mysterious were the conceptual streams science for its early practitioners. Taking into account that modern historiography (Pisano, 2009 and refs) reached the conviction that Leonardo got his results in part from other sources or that he would have written them previously together with other authors, we can reasonably make the hypothesis that the abundance of materials about his scripts and the lack of it in other cases could also be due to greater care when searching the documents of the brilliant scholar. Therefore it is difficult to make a hypotheses about an artist's inspiration. In fact, without a proper method of historical inquiry it is not so easy to deduce from his manuscripts what one author takes from another and what really represents scientific continuity or discontinuity (Pisano, 2009a, 2009b).

Leonardo's mechanics speeches are effetely scattered notes, often repeated with slight variations, sometimes with inconsistencies. Although attempts were made to reach a chronologically consistent order, the different scholars have not yet obtained results sufficiently shared, also because Leonardo had the habit of putting his hands to the manuscripts and edit them with continuous additions and deletions (Capecchi \& Pisano, 2013). The only valid criterion is the search for the logical consistency and the persistence of certain statements over others. For example:

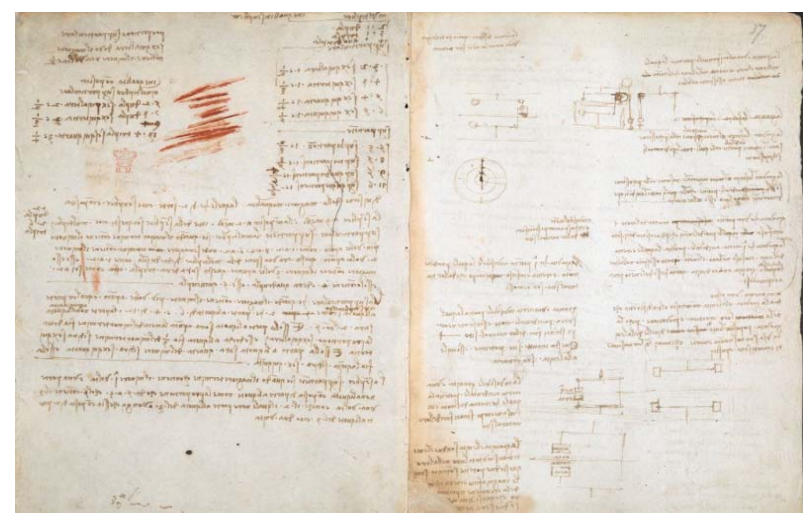

Gravity is an accidental power, which is created by motion and infused into bodies out of their natural site ${ }^{14}$

[...]

Gravity, force and accidental motion (material motion), together with percussion are the four accidental powers, by which all the evident work of mortal beings have their origin and their death ${ }^{15}$.

Figure 2.

Studies on gravity and force ${ }^{16}$ (da Vinci, Codex Arundel f. 37r).

\footnotetext{
${ }^{13}$ See, e.g., Martini's works on machines with several notes Leonardo da Vinci's hand were re-discovered.

${ }^{14}$ da Vinci, Codex Arundel f. 37r. See also: da Vinci, 1940: p 31.

${ }^{15}$ da Vinci, Codex Forster II, f. 116v. See also: da Vinci, 1940: p 32.

${ }^{16}$ The Codex Arundel is a collection (London, British Library) of papers written in his characteristic left-handed mirror-writing (reading from right to left), including diagrams, drawings and brief texts, covering a broad range of topics in science and art, as well as personal notes. It consist of 283 folia concerning physics-mechanics - and mathematics-optics and Euclidean geometry-(Euclid, 1945) architectural and territorial studies (Pedretti, 1998). Source: London British Library [via http://www.bl.uk/manuscripts].
}

Here Leonardo refers to the four powers (with a modern language, forces). Regarding the gravity it can be said that Leonardo married the Aristotelian thesis considering it as the tendency of bodies to reach their natural place ${ }^{17}$. For Leonardo gravity is caused by motion:

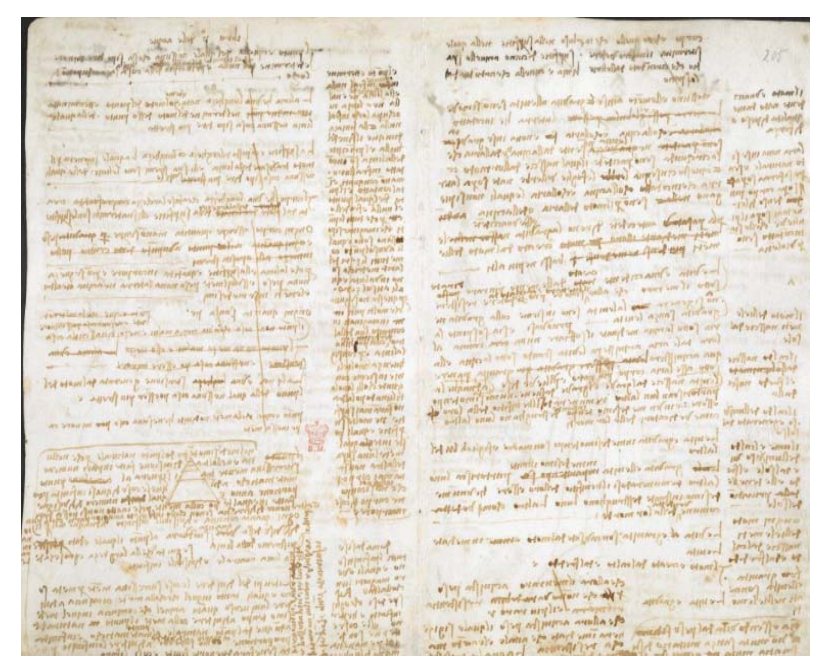

No element has in itself gravity or levity if it does not move. The earth is in contact with the air and water and has in itself neither gravity nor levity; it has not stimulus neither from the water nor from the surrounding air, unless by accident, which originates by motion. And this teaches us the leaves of herbs, born above the earth, which is in contact with the water and the air, which do not bend if not for the motion of air or water ${ }^{18}$.

$[\ldots]$

Gravity be an accident created by the motion of the lower elements into the upper $^{19}$.

Figure 3.

Studies on gravity (da Vinci, Codex Arundel f. 205r).

In brief, a body shows its gravity if, following an upheaval of the underlying parts, an imbalance of the upper parts is determined (Capecchi \& Pisano, 2013). More problematic is the interpretation of the term force. On the purpose, quite clarifying was the following famous quotation, which is interesting from a literary point of view also, as a very effective example of scientific prose, in which studies have suggested the influence of the neo-Platonic philosophy of universal animation (Ivi).

It seems the impetus of scholastic conception (i.e., Oresme, Buridanus) which is generated in the bodies by the motion transmitted to it by another body, for example by the hand that launches a stone. Leonardo distinguishes between natural gravity and accidental gravity (Capecchi \& Pisano 2013). The former is the ordinary one and is invariant, the latter is not clearly defined or at least is not defined in a unique way. According to Duhem (Duhem, 1905-1906: I, pp. 114-115; Duhem, 19061913), this term was used by the schoolmen as a synonym of impetus and Leonardo, following the ideas of Albert of Saxony (ca. 1316-1390) who assumed the natural gravity concentrated in the centre of gravity, would consider also the accidental concentrated in a point, named the centre of accidental gravity:

\footnotetext{
${ }^{17}$ On that some arguments, sometime forced are in: Duhem, 1905-1906: I, pp. 16-17.

${ }^{18}$ da Vinci, Codex Arundel, f. 205r. See also: da Vinci, 1940: p 30

${ }^{19}$ Ibidem.
} 


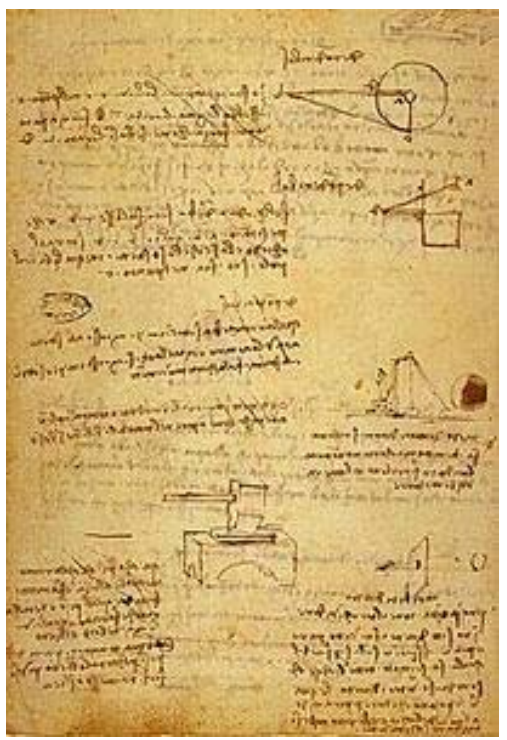

Force I say to be a strong spiritual virtue, an invisible power, which is caused by accidental external violence of motion and placed and infused into bodies, which are moved from their natural habit [the rest] and bent by giving them active life of wonderful power: constrains all created things to change form and site, runs with fury to her desired death and comes diversifying through the causes. Slowness makes her great and quickness weak, she comes into being from violence and dies for freedom and the greater the sooner is she consumed. Drives away in a rage what is opposed to her decay; she wants winning, to kill by her causes any constraints and winning, she kills herself. She becomes stronger where she finds a stronger contrast. Nothing will move without her. The body from which she originates does not change form or weight ${ }^{20}$.

Figure 4.

Studies of the equilibrium of weights and of impact ("percossa") (1) (da Vinci, MS. A f. 1v).

Each body has three centres of figure, one of which is a natural centre of gravity, the other of the accidental gravity and the third one of the magnitude ${ }^{22}$.

\section{On Leonardo's Approach to Statics Science}

Leonardo's contribution to statics (Pisano, 2009a; Capecchi $\&$ Pisano, 2007) concerns the rule of composition-decomposition of a force along two given directions. The problem to be solved was to find the tensions of two inclined ropes supporting a weight. The forces of the ropes also were associated with weights ${ }^{23}$.

Leonardo besides to formulate the rule also correctly proved $\mathrm{it}^{24}$. The analysis of texts has however led us to believe that in this case Marcolongo's analysis is correct and actually Leo-

\footnotetext{
${ }^{20}$ da Vinci, Ms. A, f. 34v. See also: da Vinci, 1940: pp. 253-254.

${ }^{21}$ Source: Istituto e Museo di Storia della Scienza, Firenze, Italy [via http://brunelleschi.imss.fi.it]

${ }^{22}$ da Vinci, Codex Atlanticus f. 188v (b). See also: da Vinci, 1940: p. 45.

${ }^{23}$ Of course the modern difference between force-weight (vectorial quantity) and mass (scalar quantity) is taken into account.

${ }^{24}$ This is normally not recognized by historians and even Duhem (who did not study the Codex Arundel) suggested only as a possibility that Leonardo understood the rule. Marcolongo only asserted with no doubt his priority.
}

nardo recognized the rule of weight distribution in two ropes supporting a weight. There are of course, as typical in Leonardo (Pisano, 2009a), situations in which the rule is loosely worded, and sometimes wrongly (Capecchi \& Pisano, 2013). However, although there are no certain dating criteria, the analysis of the manuscripts shows a long series of examples with a lot of correct arguments that can leave no doubt that Leonardo reached a conscious knowledge of the rule of composition of forces. The following quotations start from the intuitive finding that the weight distribution depends on the obliquity of the ropes.

On weight. If two ropes converge to support a heavy body, one of which is vertical the other oblique, the oblique one does not sustain any part of the weight.

But if two oblique ropes would support a weight, the proportion of weight to weight would be as the obliquity to obliquity.

For ropes that descend with different obliquity from the same height, to support a weight, the proportion of the accidental weight of the ropes is the same as that of the length of these ropes ${ }^{25}$.

Here by using the word obliquity, Leonardo rather than to the slope refers to the length of the ropes - see the final part of the previous quotation - while the accidental weight could be understood as the tension of the ropes. The statement is patently incorrect, but one could think that Leonardo had confused and meant to speak of the inverse ratio of obliquity, which is still wrong but at least the tendency is correct. In the following passage Leonardo's is not a typo, because he clearly states that the weight is divided into proportion of the angles formed by the ropes with the vertical, which is clearly false (Capecchi and Pisano 2013):

Let consider two lines concurring in the angle which sustains the weight, if you draw the perpendicular which divides this angle, then the weights [tensions] of the two ropes have the same ratio as that of the two angles generated by the above division. If between the two lines $a c$ and $e c$, which form the angle $c$, from which the weight $f$ is suspended, the perpendicular dc is drawn that divides this angle into two angles acd and $d f e$, we say that these ropes will receive the weight in proportion equal to that of the two angles they form and equal to the proportion of the two triangles. And the perpendicular that divides the angle of this triangle will split the gravity suspended in two equal parts, because passing through the centre of such gravity ${ }^{26}$.

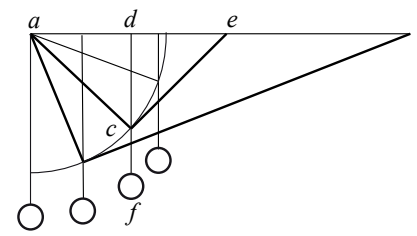

(a)

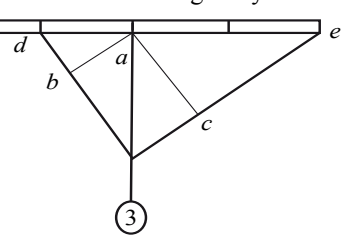

(b)
Figure 5.

(a) A wrong instance of decomposition of forces ${ }^{27}$; (b) A correct instance of decomposition of forces ${ }^{28}$.

It is reasonable to suppose (Capecchi, 2012; Capecchi \& Pisano, 2013) that Leonardo might have thought to a weight hanging from the middle of a rope in which the greater the obliquity - i.e. the angle they form with the vertical - the larger the tensions in the rope (Ivi).

\footnotetext{
${ }^{25}$ da Vinci Ms. E f. 70 r. See also: da Vinci, 1940: p. 142

${ }^{26}$ da Vinci, Ms. E f. 71r. See also: da Vinci, 1940: p. 143.

${ }^{27}$ Capecchi \& Pisano, 2013.

${ }^{28}$ Ibidem.
} 
Marcolongo (Marcolongo, 1932) argues, however, that these wrong results date back to the years before 1508, when Leonardo had not yet reached his final idea which is well expressed in the passage:

For the sixth and ninth [propositions], the weight 3 does not split into the two real arms of the balance in the same proportion of these arms, but in the proportion of the potential arms ${ }^{29}$.

Here Leonardo asserts, without proving it, that the suspended weight is supported by tensions $b$ (left) and $c$ (right) having inverse ratio to the potential arms $a b$ and $a c$, i.e.: $b: c=a: a b$. The relation, correctly, allows to find the ratio of tensions in the two ropes (Capecchi \& Pisano, 2013).

In other Codex, Leonardo proves the asserted relation and also indicates the way to evaluate the absolute value of the tension in each rope. He introduces the terms: potential lever and potential counter lever (Ivi). The potential lever corresponds someway to the potential arm, the potential counter lever is the horizontal segment connecting one support of a rope to the vertical from the suspended weight. The reading of the following quotation is useful to illustrate the use of these terms. The potential lever associated to the $\operatorname{arm} f m$ is $f e$, the potential counter lever is $f a$.

Here the weight is sustained by two powers, i.e. $m f$ and $m b$. Now we have to find the potential lever and counter lever of the two powers. The lever $f e$ and the counter lever $f a$ will correspond to the power $m b$. The appendix $e b$ is added to the lever $f e$, which is connected with the engine $b$; and the appendix $a b$ is added to the counter lever $f a$, which sustains the weight $n$. By having endowed the balance with the power and the resistance of engine and weight, the proportion between the lever $f e$ and the counter lever $a b$ should be known. Let $f e$ be $21 / 22$ of the counter lever $f a$. Then $b$ supports 22 when the weight $n$ is $21^{30}$.

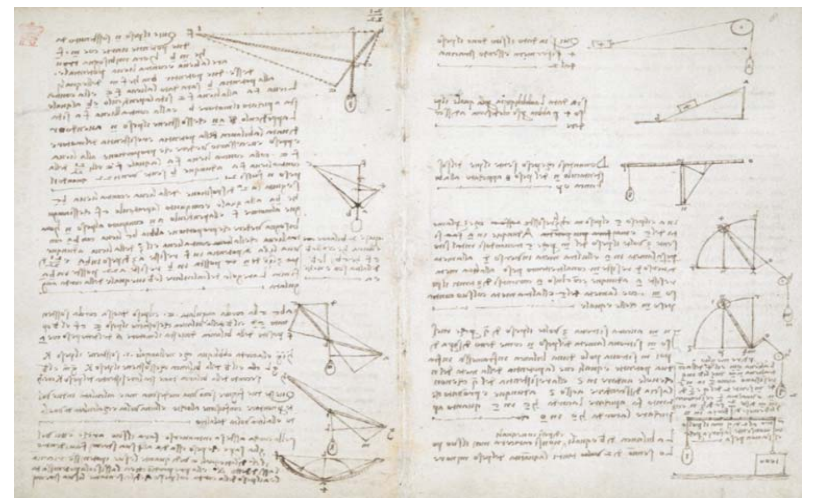

(a)

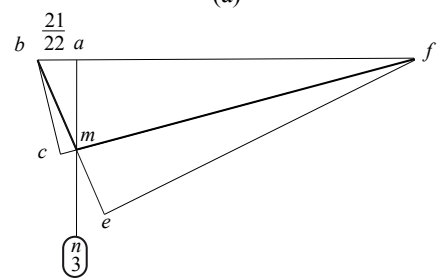

(b)

Figure 6.

(a) Studies on levers ${ }^{31}$ (da Vinci, Codex Arundel f. 7v); (b) Potential lever and potential counter leve ${ }^{32}$.

\footnotetext{
${ }^{29}$ da Vinci, Codex Arundel, f. 1v. See also: da Vinci, 1940: p. 171.

${ }^{30} \mathrm{da}$ Vinci, Codex Arundel, f. 7v. See also: da Vinci, 1940: p. 179.

${ }^{31}$ Source: British Library [via http://www.bl.uk/manuscripts].

${ }^{32}$ Capecchi \& Pisano, 2013.
}

Attention is centred on the rope $b m$ with the aim to find its tension. A similar argumentation can be repeated for the rope $\mathrm{fm}$. Basically Leonardo imagines the rope $\mathrm{fm}$ as solidified, i.e. as a rigid beam hinged at $f$. According to his embryonic concept of moment of a force, Leonardo asserts the validity of the following relation: $b: n=f a: f e$, where $b$ is the tension of the rope $b m$ and $n$ is the suspended weight. He gives as an example $f a: f e$ $=21: 22$; for $n=21$ it results $b=22$. Previous quotation deserves some comments. First: the idea to solidify the rope anticipates what is commonly named solidification principle, according to which if a body is in equilibrium its state is not perturbed by adding additional constraints ${ }^{33}$.

In others folia Leonardo da Vinci's observations on beams concern either the axial and flexional behaviour. For this last issue he focused more attention on its buckling. These considerations are interesting though not always formal and precise experimentally.

Finally, Leonardo is more concerned with deformability than strength (Capecchi \& Pisano, 2013). The reason could be that he refers mainly to the timber used in building-war-machines and ships.

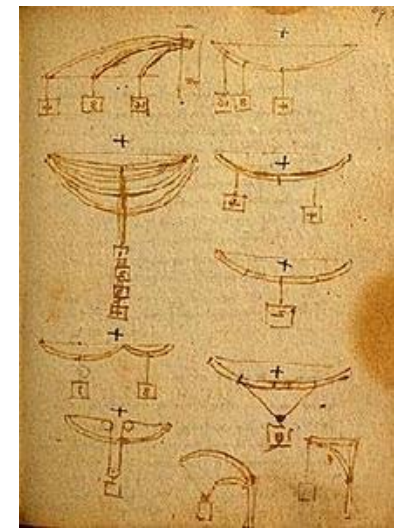

Figure 7.

Studies on beam ${ }^{34}$ (da Vinci, Codex Forster II, f. 89v).

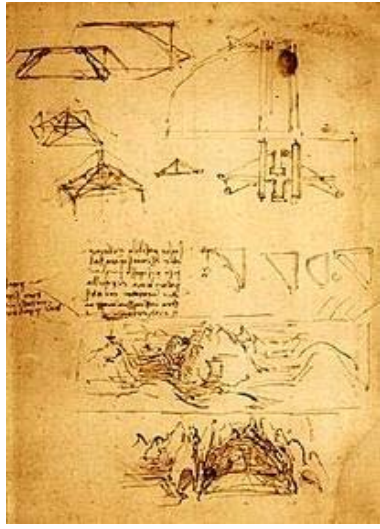

Figure 8.

Studies of the resistance of arches ${ }^{35}$ (da Vinci, Codex Arundel, f. 224r).
These beams are very thick and resistant to failure, so they are essentially dimensioned for deformation.

[A] One beam of 6 braccia is stiffer the double in its middle, than four equal sized beams of 12 braccia joined together $^{36}$.

Based on recent researches (Pisano, 2009; Capecchi \& Pisano, 2010, 2013), the previous observation of Leonardo is in accordance with modern theory of elasticity of beams: a supported beam of constant section, highlighted $l$ by means of a concentred force $f$ applied to mezzeria.

The arrow $v$ is mathematically interpreted by the following formula:

$$
v=\frac{1}{48} \frac{f l^{3}}{E I}
$$

\footnotetext{
${ }^{33}$ This principle has been used to study deformable bodies by many scientists, including Stevin, (Dijksterhuis, 1955), Lagrange, Cauchy, Poinsot, Duhem (Capecchi, 2012; Pisano \& Capecchi, 2013).

${ }^{34}$ Source: Istituto e Museo di Storia della Scienza, Firenze, Italy [via http://brunelleschi.imss.fi.it].

${ }^{35}$ Ibidem

${ }^{36}$ da Vinci L, Codex Atlanticus, f. 211 rb, [p. 562r].
} 
where $E$ is the longitudinal modulus and $I$ the moment of inertia of the section. From the previous track and considering (1), from 6 to 12 arms, that is, doubling the light, the same section and force $f$ by formula above the arrow increased 8 times or rigidezza (rigidity) decreases 8 times. But 4 of 12 auctions arms absorb each $1 / 4$ of the force $f$ to which the arrow of four auctions together is equal to that of an individual charged with $1 / 4$ $f$. The fall of each beam of 12 arms worth $1 / 4$ to 8 times so it is only 2 times that of an arm of 6 . It is thus the result of Leonardo in $[\mathrm{A}]$.

\section{On Leonardo's Approach to Mathematical Science}

Nowadays Leonardo da Vinci's cultural matrix seems clear. Historians agree in considering the Aristotelian physics as the main source of his mechanics. According to such studies from the analysis of Codex by Leonardo, it was possible to deduce some of the titles of the manuscripts ${ }^{37}$, not entirely scientific, used by Leonardo for the researches: Abū Yūsuf Ya qūb ibn Ishạa al-Kindī (801-873 A.C.) Libellum sex quantitatum, Gaius Plinius Secundus called Pliny the Elder (23-79 A.C.), Naturalis Historia, Aristotle ${ }^{38}$, De phisica and De metheoris, Euclid, De ponderibus, De levi et ponderoso fragmentum, John Peckham (1225 ca-1292) Perspective ciommunis, Piero de' Crescenzi (1233-1320?) De Agricultura, Mondino de' Liuzzi (1270-1326) Anathomia, Paolo dell'Abaco (1282-1374) Recholuzze del maestro Pagolo astrolacho, Leon Battista Alberti (1404-1472) De pictura, Cristoforo Landino (1424-1498) Formulario di epistole volgari, Francesco di Giorgio Martini (1439-1501) Trattato di architettura militare e civile, Giovanni di Mandinilla, Tractato delle più maravigliose cosse e più notabili, Luca Pacioli, De divina proportione, and Giorgio Valla (14471500) De expetendis et fugiendis rebus, etc. Thus, even if Leonardo da Vinci's research works concern almost exclusively the fields he practiced as a technician, a need of a mathematiccal-geometrical $^{39}$ abstraction and of rationalization seems to emerge; apparently neglected until then by technicians, there was an exigency to define technique through observation and the mathematical explanation of phenomena. Nonetheless it is worth remarking that a consequence of this early form of discontinuity is the fact that Leonardo da Vinci's method surely did not spring out of nowhere. It is rooted in the scientific tradition of the Aristotelian school, further than in the Archimedean one. More specifically, many are the traces of Aristotle' thought to be found in Leonardo, starting with the concept that the knowledge of universal things (the furthest from our senses, in contrast with the singular things which are the closest to our sensible perception) is acquired by means of reasoning based on primitive truths that cannot be proved; the latter can be known by induction, that is by means of data of the sensible perception stored in our memory.

At the same time, Leonardo draws on Archimedes' scientia,

\footnotetext{
${ }^{37}$ Leonardo did not finish his speeches on On the sky (Sul cielo) and On the world (Sul mondo) would have to combine the researches of astronomy to those of geology. The few notes that there are often appear contradictory: on the one hand they show that Leonardo believed the Earth at the center of the system, on the other hand sometimes express concern about the motion of the Sun. In some passages only the comments around celestial bodies was then reduced to issues of lighting, within art and science speculations.

${ }^{38}$ See also: Aristotle, 1853, 1949, 1955a, 1955b, 1963, 1984, 1996, 1999; Cartelon.

${ }^{39} \mathrm{An}$ interesting work on geometry during Islam period is Maitte, 2003.
}

in particular he shares the methodology based on the mathematical and geometrical study of the equilibrium that is he follows the rational criteria that the mathematician from Syracuse had set to determine the centres of gravity. Thus the relationship between Leonardo and the mathematics were influenced by many factors, especially his close friendship with Luca Pacioli. Nevertheless his results were enough immature with respect to the deep mathematical ideas born by Luca. In the following attempts by Leonardo to work with fractions before his meeting with Luca Pacioli is reported:

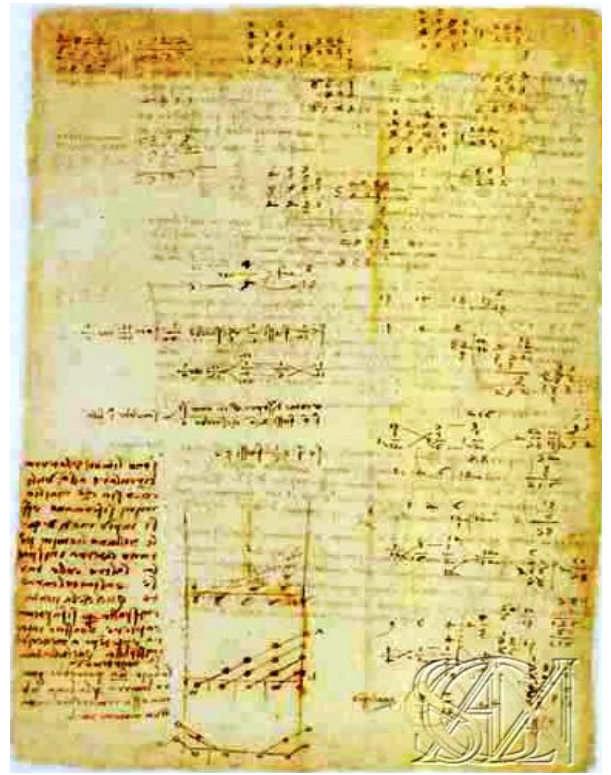

[Leonardo wrote]

$$
\text { "sarà } \frac{12}{12} \text { cioè } \frac{1}{0}[\ldots] " \text { " [...] } 1 \frac{1}{12}, 1 \frac{1}{2} \quad[\ldots] \text { " }
$$

[Then, he correctly transforms in " $[\ldots] \frac{13}{12}, \frac{7}{6}, \frac{3}{2}[\ldots]$ "

[Now he sums these 3 fractions and obtains:] $\frac{216}{78}$

[Of course the result is wrong. The right one is

$$
\frac{45}{12} \text { that is } \frac{15}{4}
$$

[He confused " 12 " as denominator. Idem ambiguous calculus are possible to read in the Codex $L, \mathrm{f} .10 \mathrm{v}, \mathrm{f}$. $21 \mathrm{v}^{40}$ and in the Codex Atlantico, f. 665r (Bagni \& D'amore, 2007)].

Figure 9.

Rules to calculate fractions (da Vinci, Codex Atlanticus $^{41}$ f. 191v)

\footnotetext{
${ }^{40}$ The Codex $L$ is part of a set of manuscripts: $A, B, C, D, E, F, G, H, I, K, L$, $M$. They are archived at the Institute of France, Paris (France). They consist of twelve manuscripts, some bound in parchment, leather or cardboard. They have different sizes, the smaller one is the number $\mathrm{M}(10 \times 7 \mathrm{~cm})$, the larger one is $\mathrm{C}(31.5 \times 22 \mathrm{~cm})$. By convention each of them are named by a letter of the alphabet, from A to M (omitting J), for a total of 964 folia. The topics covers from military art, optics, geometry, hydraulic and flight of birds. A probably date might be fl. 1492-1516. Source: Istituto e Museo di Storia della Scienza, Firenze, Italy [via http://brunelleschi.imss.fi.it].

${ }^{41}$ The codex is the largest collection of Leonardo's sheets (end of the sixteenth century by the sculptor Pompeo Leoni (1531-1608) who dismembered many original notebooks. ca. 1478-1518 and consists of 1119 sheets. It is archived in Biblioteca Ambrosiana Milano, Italy and contains studies on science and technology, architectural projects, town planning, biographical records and personal notes. Source: Biblioteca Ambrosiana [via http://www.ambrosiana.eu].
} 


\section{On the Scientific Relationship between Leonardo and Luca}

By considering the complexity and the huge literature on $\mathrm{Pa}$ cioli's mathematics, before focusing on Pacioli-da Vinci scientific relationship, just few notes on Pacioli's arithmetical approach are reported.

The theory of proportions ${ }^{42}$ plays a central role in the project of mathematization of knowledge proposed by Pacioli. It is interesting to remark the fifth $^{43}$ book of Euclid's Elements. It derived and commented by second part of the VI Distinction in the Summa de arithmetica, geometria, proportioni et proporzionalità (1494) where Pacioli claims his definitions of proportionality ${ }^{44}$.

If you well study, in all arts, you will found the proportion as the mother and queen of all of them, and without it you cannot exertion $^{45}$.

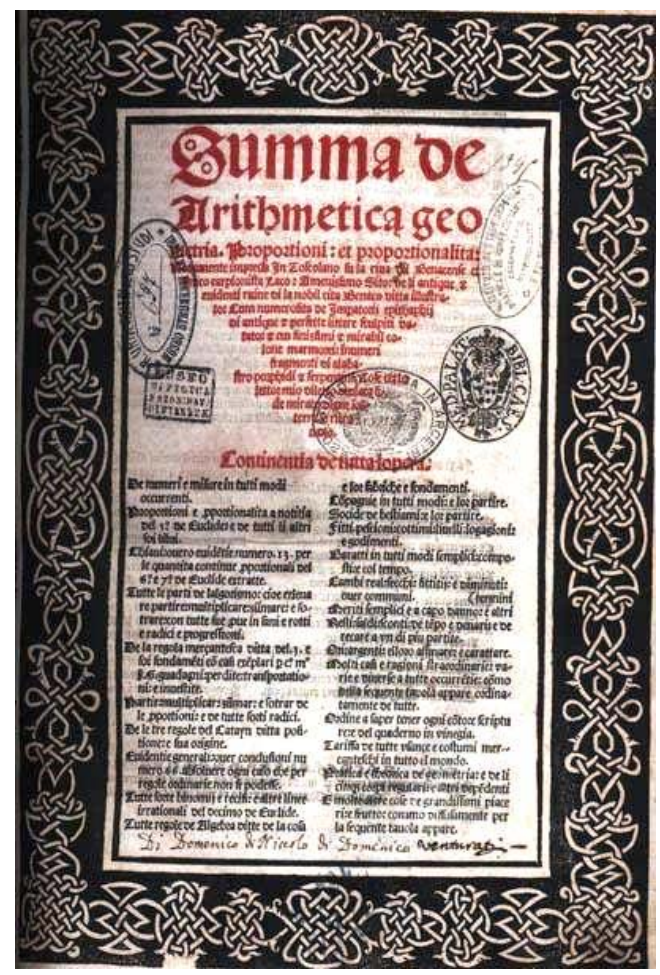

Figure 10.

Plate from Summa by Pacioli (Pacioli, Summa, f. 1r) ${ }^{46}$.

\footnotetext{
${ }^{42}$ Since the literature on Pacioli is very large, some examples and maybe more adequate arguments are reported only.

${ }^{43}$ In vulgare text by Federico Commandino (1509-1575) the definitions are: "[V, Def. 5] Magnitudes are said to be in the same ratio, the first to the second and the third to the fourth, when, if any equimultiples whatever are taken of the first and third, and any equimultiples whatever of the second and fourth, the former equimultiples alike exceed, are alike equal to, or alike fall short of, the latter equimultiples respectively taken in corresponding order [...]. [V, Def. 6] Let magnitudes which have the same ratio be called proportional." (Commandino, 1575, Defs. 5-6; see also Commandino, 1565).

${ }^{44}$ "Dico con Euclide in quinto proportionalità in communi ene solo similitudine de più proportioni e al manco de doi" (Pacioli, Summa, 72v).

${ }^{45}$ Pacioli, Summa, $78 \mathrm{v}$.

${ }^{46}$ Source: Max Planck Institute for the History of science- Echo/Archimedes Project [via

http://echo.mpiwg-berlin.mpg.de/content/historymechanics/archimdesecho/ archimedes-intro].
}

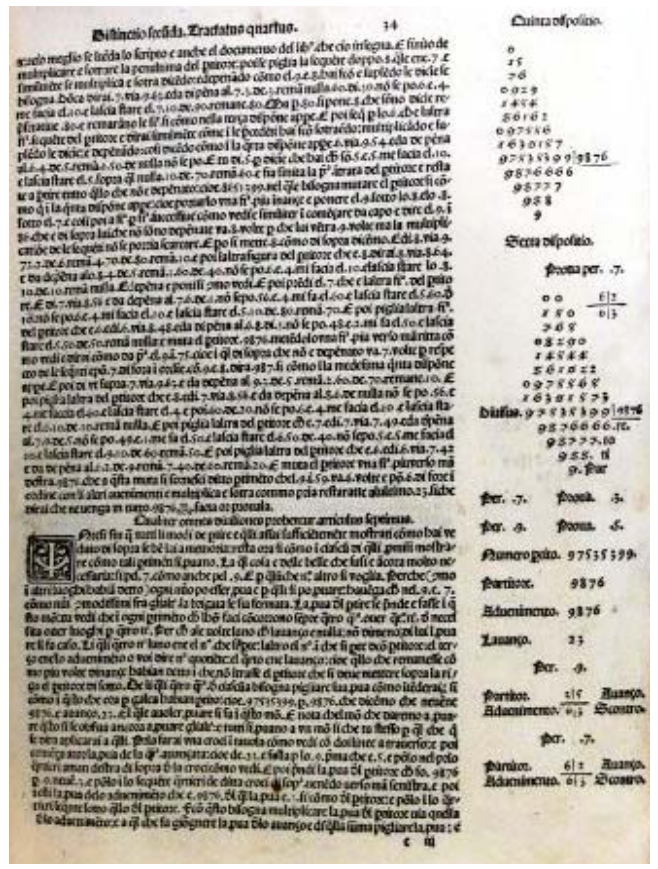

Figure 11.

Mathematical arguing in Pacioli’s Summa (Pacioli, Summa, f. $34 \mathrm{r})^{47}$.

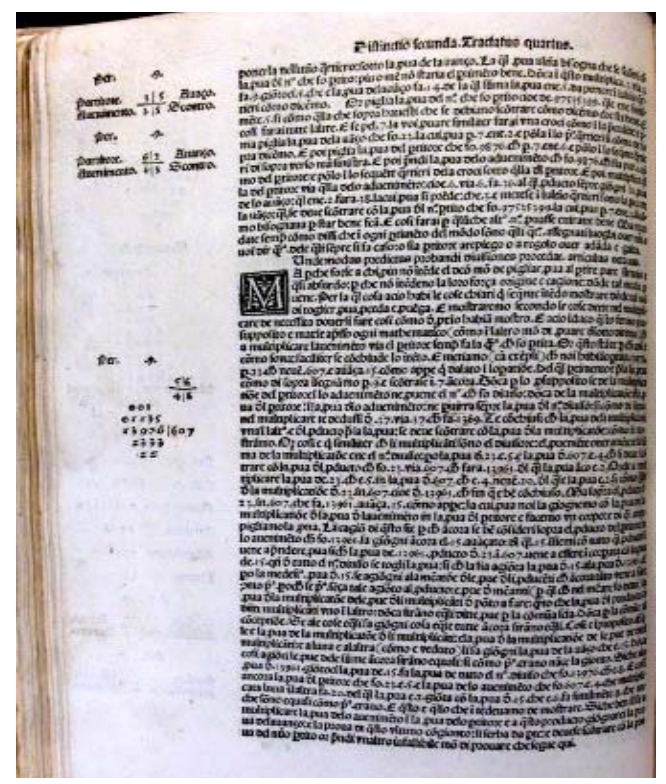

In a modern formalism. Given four proportional quantities

$$
x: y=z: w
$$

being $m$ equimultiple of the first and third, and being $n$ equimultiple for the second and fourth, one obtain:

$$
\begin{gathered}
m a=n y \text { and } m z<n w \\
m a>n y \text { and } m z=n w \\
m a>n y \text { and } m z<n w \\
m a>n y \text { and } m z>n w \text { with } m x / n y>m z / n w \\
m a<n y \text { and } m z<n w \text { with } m x / n y<m z / n w
\end{gathered}
$$

Figure 12.

Mathematical arguing in Pacioli's Summa (Pacioli, Summa, f. $34 \mathrm{v})^{48}$.

\footnotetext{
${ }^{47}$ Source: Ibidem

${ }^{48}$ Ibidem.
} 
non si pessa fauere' nottia si commo de $l_{0}>^{\circ}$ effecto soura dicemmo. Onde. poni chel numor pensato fasse. $t z$. Dopealo fa $=4$. orogni.s. fa z. multiplicba per.s. fa. 14 s. grooni lo fa. iss mutripheba per.10. fa is so.cauane. 3 so refta. 1 zo0. parti in 100 . neucn iz per lo niloze Vol dire la ditta regola ch' partendo lultimo nepto.per too.ch tante unita siranno in quel tal numero quanti semenno gli centenari cbs. Gontuna isopra gli centenari entegri alcuna. cosa neftara tal partic o, nern partitolse piu de ditte unita quale o, uer quali ditto auanze del partamento sina de 200 . cioe se auanzasse zs ch'son un $\frac{1}{4}$ de 100 .cosi lui presse' piu un quarto de unitas et se fosse auan ato. 75.ch'so' $\frac{3}{3}$ de 100. et 3 preßd piu de una unita eltra sani se ui sonno:Nono effecto a trouar un $N \mathcal{u}$ senza rotto:

P Er certe altre for anchora pastamo peruenir alla notitia de un numero pensato qual nò sia mescolato con roito alcuno si commo fo detto sopra nello effecto.7. in quefto mode.us.cht th facia multiplucar' dilto ñi per. 3 .et lo producho

Ninth effect for seeking a number without fraction [rotto]: [In modern language, given $x$, by using Fibonacci, we can calculate:] [...]

$$
\frac{3 \frac{3 x}{2}}{9}=\frac{x}{4}
$$

Figure 13.

On the fractions (Pacioli, Viribus, 20v, 21r) ${ }^{49}$.

\begin{abstract}
el suo numero de ducesse cose' acio para piu bello et ate scusa memonia artefictali assettandote an chora el numero dele cose' ch' th a torno dant se condo qualch memorial proportioni commo dupla tripla sexquialiteria sexquitertia ces acso tutte te aturne fra tanti arecordartand oy Et da poi Dini a cada uno cb' prenda altrctrit' per numero dich' moneta si uggheno ch' uaglia pris dela prima per membriga et ch'ate dichino le monete prime et seconde ggnuno la sua et tw attenderai ale lor ualuté commo dosopra e' detto et sumul et semel a tuth aun tratto potrai dire

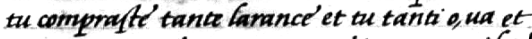
tutant' starne' ct tu tants tondi et to tant becha fichi ch'siva tenuta una ftupenda cosa maxime quatdo con certm gnatia datt simil gentrlezzesiran propofe peroch' tutte gli cose' tarto sino of?Cle' quanto lomo le sa adornare' cosi indire commo in fare ch' tutto la sperrentia ci fa chiam cze XXX-1111 efferto afinire qualunch' numero na' ceal compagno anon prendere piu de un termiato $h$. Somme dale preditte for ze non da eqere' exclusi alcuni gligradri gusochi bonefte et lecit matbema. the quali comstruma imente se sofiano per ficorte
\end{abstract}

XXXIIII effect to finish whatever number is before the company, not taking more than a limiting number. [...] [For example two persons must reach 30 by summing alternatively numbers between 1 and 6 . The one who reaches 30 wins. The artifice consists in making choice of the numbers $2,9,16,23$. Indeed, if I reach 23 , as my opponent can only add a number between 1 and 6 , he will reach at most 29 and I just have to add 1 to win. We find the other safe numbers with backward reasoning].

Figure 14.

On the recreational maths games (Pacioli, Viribus, $73 \mathrm{v}-74 \mathrm{r})^{50}$.

\footnotetext{
${ }^{49}$ Source: Biblioteca Universitaria di Bologna [via

http://www.uriland.it/matematica/DeViribus].

${ }^{50}$ Ibidem.
}

With concern Leonardo, he wrote down earlier meeting with Pacioli, transcripts of his handful of whole passages of the Summa. On 10th November 1494, in Venice, finally released in print in Latin, Luca Pacioli's Summa arithmetic, geometry, proportions et proportionality. Luca inspired Leonardo, and he was counselor, teacher and translator. Leonardo bought Summa (119 soldi) as he claimed (da Vinci, Codex Atlanticus, f. 288r f. 104r, f. 331 r) and notes: "Learn multiplication of the roots by master Luca" (da Vinci, Codice Atlanticus, f. 331r [120r]). Thus, from 1496 to 1504 Leonardo studied Luca Pacioli's works and summarizes his theory of proportions (da Vinci, Codex Madrid, 8936). Based on that, he expressed his interest in geometry expressing both in the drawings for De divina proportione ([1496-98] 1509), that for his readings on Euclid (clearly only for first 6 books and part of the tenth. Leonardo faced the problem of irrational numbers, the ratio between incommensurable segments, side and diagonal of the square, the radius and the circumference and the problem of the socalled deaf roots (radici sorde).

Thus, after his meeting (1496) with Luca, Leonardo was busy in geometry and mechanics adopting new mathematical and geometrical assumptions forwarded by Maestro Luca. In the following examples on geometrical and mechanical problems are reported:

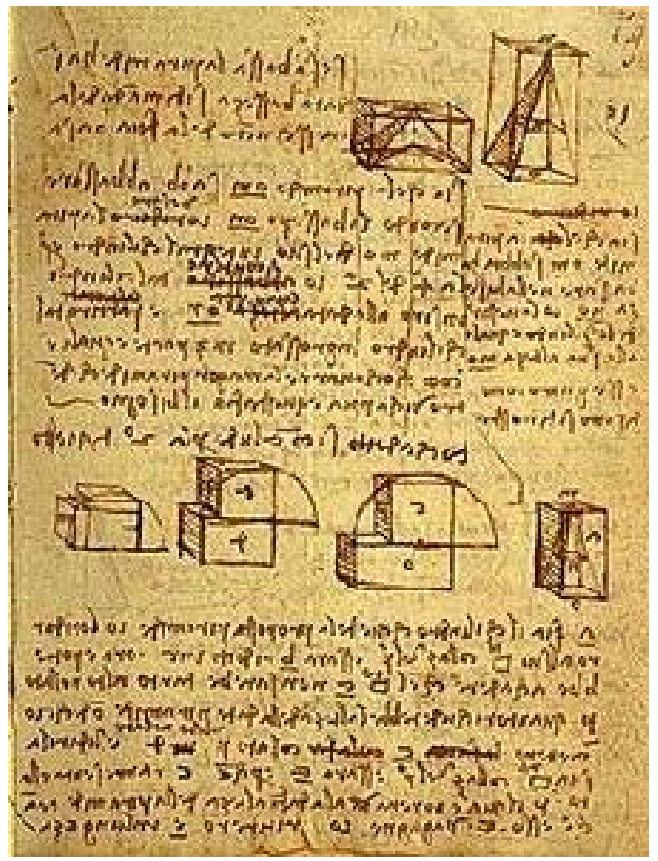

Figure 15.

Stereometric studies after Leonardo and Luca meeting ${ }^{51}$ (da Vinci, Codex Forster I, f. 19r).

Particularly geometrical figures were presented for the first time in the Codex Forster ${ }^{52}$ and finally included De divina proportione (1498) are evident examples.

\footnotetext{
${ }^{51}$ Source: Istituto e Museo di Storia della Scienza, Firenze, Italy [via http://brunelleschi.imss.fi.it].

${ }^{52}$ This Codex Forster is composed of two manuscripts totalling 159 leaves. The Ms. I (1497) presents studies of mechanics, ornamental knots and plaits and of architecture. The Ms II (1495) records Leonardo's research in physics and mechanics (force, gravity, weight and movement). Particularly the Codex Forster I from f. $14 \mathrm{r}$ to f. 22 r includes speeches on Summa's theory.
} 
Generally speaking, Leonardo tried to develop a process of theoretical and experimental research (Rogers) that starts from tasks and requirements of a practical nature and then develops theoretical considerations, compared with the classical and medieval primary sources of scientific knowledge, to be verified experimentally, in order to build up general mathematical rules applicable to specific cases. Particularly he used pragmatic and realistic approach to the mathematical problems. Leonardo does not seek absolute rigour in the results of his research, but an approximation recognized as useful, clearly an attempt to rationalize all human activities, including his own (Pisano, 2009; Pisano \& Rougetet, 2013).

With Leonardo, it very often recurs, perhaps for the first time, the idea of an absolutely efficient building-machine (Pedretti, 1978, 1999). Within it daily activities are made rational and mechanic: e.g. a fireplace automatically operated, a laundry, the model of a stable. The building is conceived as a living organism but, at the same time, in a sense, taking Vitruvio' concepts to the extreme, he suggests also the way round. In other words, living organisms too-men and animals - are turned into machines. In this sense, he detects in any organism, living or not, a unity of process and function based on movement and considers animals as a human body and buildings as a whole of mechanical devices, that he calls elementi macchinali (machineries) Bird is a device performing after a mathematical law and nature cannot make animals move without mechanical devices Leonardo da Vinci's considerations around such mechanical elements and his studies of anatomy are really interesting, proving study and performance methods very similar. This uniformity of treatment emerges in his drawings as well, either anatomic, where bones and muscles are handled as geometrical schemes of ingegni $i^{53}$, or of machines and tools, in which relevant specific elements insist, such as the cannons-columns ${ }^{54}$ that seem to claim the universality of the planning project. Thus, it is evident that the studies by Leonardo represent an important and partly correct attempt to formulate a general theoretical organization involving greater formalization - than his predecessors-which can clear up and preview, e.g. the deformability of bodies in mechanics and architecture. One of his aims was to avoid further planning mistakes to ensure the proper functioning of the building-human organism and of the building-machine ${ }^{55}$.

Unlike Leonardo, Luca implemented an artimetization of the theory of proportions (Pacioli's Summa, 77-78rv) which is based on the Book $V$, and above based on the Book VII (the first of the three arithmetic books of the Elements) that provided to use the proportions in practical scope of the calculation, and using the concept of denominator. The subject of the proportions is the core of the scientific program of mathematization pursued by Luca. The latter adopted a practice to use ratio by the denominators, since he frequently adopted Euclidean defi-

\footnotetext{
${ }^{53} \mathrm{da}$ Vinci, Codex Windsor, RL 12656; see also f. 17r.

${ }^{54} \mathrm{da}$ Vinci, Codex Atlanticus, f. $28 \mathrm{v}$.

${ }^{55}$ In this way he is remote from his contemporaries. Later, toward the end of the Renaissance this new way to decide the theory that assumed a particular cultural value mainly proceeding towards an analytical perspective of conceiving mechanics that seemed to be coming to a crossroads: physical or mathematical science? That way another historiographic problem emerges (Pisano, 2009; Pisano \& Gaudiello, 2009): a crucial continuity-discontinuity problem appears when a theory is included in another theory, e.g. mathematics in mechanics (rational mechanics), astronomy in mechanics (celestial mechanics) mathematics in thermodynamics (analytical theory of heat), mechanics in engineering (structural mechanics).
}

nitions of in the seventh book of the Elements, equivalently of practice use adopted at that time by non mathematicians, that is by philosophers. At that stage he uses which the selected list of names as presented in the Arbor proportionis.

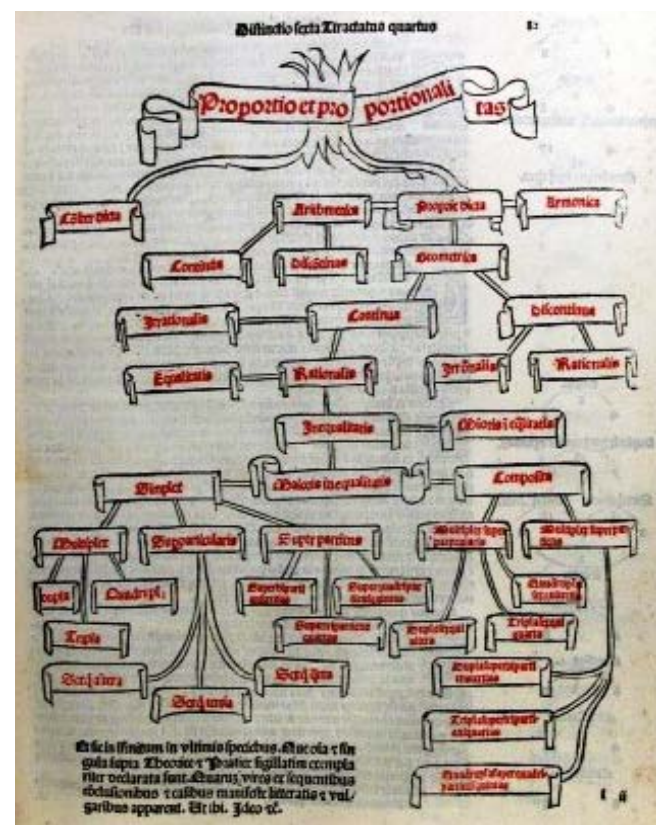

Figure 16.

The Arbor proportionis et proportionalitatis by Pacioli (Pacioli, Summa, f. 82r).

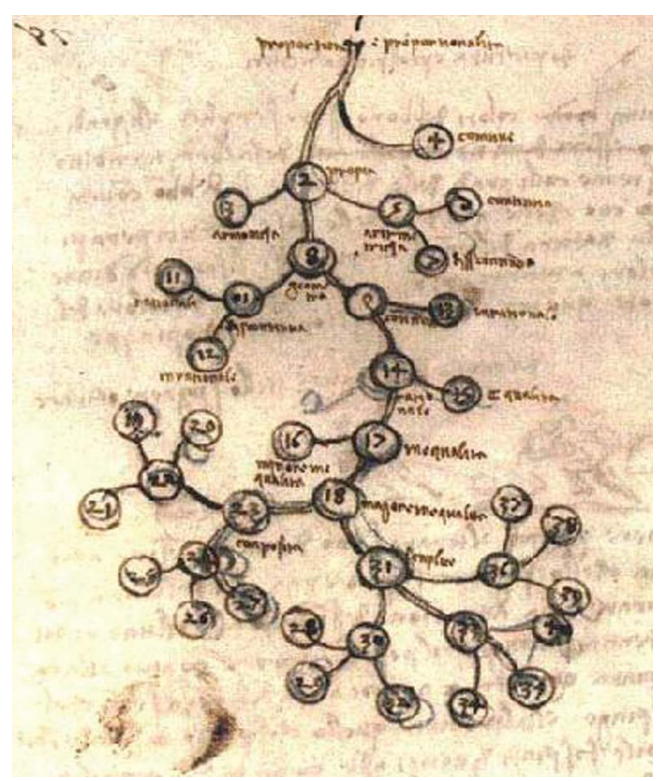

Figure 17.

The Arbor proportionis et proportionalitatis by Leonardo (adapted by Pacioli's Arbor) (da Vinci, Codex Madrid, Ms. II, f. $78 \mathrm{r})^{56}$.

\footnotetext{
${ }^{56}$ The Codex Madrid is a recent Codex rediscovered in 1966 consists of 157 folia concerning Leonardo's activity in Firenze on plans for military architecture carried out (Piombino), maps of the Tuscan region, notes on painting and studies of optics. A final booklet, arbitrarily attached to the manuscript, contains Leonardo's studies (1491-1493) for the casting of the equestrian monument to Francesco Sforza.
} 
Leonardo is interested in Pacioli's works and reported it his three codes (da Vinci, Madrid II, Forster II $\left(1^{\circ}\right)$; Id., Ms. K. The Codex Madrid II (da Vinci, Codex Madrid II, Ms. 8936), contains from folio $46 \mathrm{v}$ to folio 50r, a summary of the Sixth distinction of the Pacioli's Summa, dedicated to the proportions and proportionality. In fact, the Codex Forster II $\left(1^{\circ}\right)$, by folio $14 \mathrm{r}$ to folio $22 \mathrm{r}$ contains notes on the theory of proportions that lead back to the Summa. Finally in the Ms. K (da Vinci, Ms. K), dotted by numerous references to the propositions of Euclid's Elements $($ Book $\mathrm{V})$, one can read:

The proportion is not only to be found in numbers and measures, but also in sounds, weights, intervals of time, and in every active force in existence ${ }^{57}$.

The sentences belongs to Summa by Pacioli (Pacioli, Summa, f. 69r) which in turn, he belongs to the comment by Campano adapted for his Euclidean work (Pacioli, Euclidis, f. 32rv-33r). With regard to the geometry, Leonardo was interested in construction of regular polygons with ruler and compass, rather that problems of constructing a square sum of two data. On can see, e.g., the problem by dividing the circumference in $3,4,5,6$, 7, 8 equal parts up to the maximum of 48 sides (da Vinci Codex Atlanticus, f. $11 \mathrm{v}$ ). The speech are randomly distributed in the manuscripts where few precise explanations are proposed by Leonardo only adding by ragione (reasoning, a sort of proof). In effect they are not really proofs, rather they are fast explanations (da Vinci, Codex Forster III, fs. 68v-69r).

\section{Final Remarks}

Finally, Leonardo met Luca in Milan (1496). The friendship and mutual respect between the two are very strong as Pacioli wrote in the first pages of De divina proportione around a scientific challenge (duello scientifico) that took place at the court of Ludovico il Moro on the February 9, 1498, (clergy, theologians, doctors, engineers and inventors of new things and Leonardo shared it). Leonardo learnt concepts, methods, proofs and avversaria for the statement to refute (inimica). The geometry of Leonardo is therefore more cultured, and obtained by Pacioli (and indirectly by Euclid). In particular, golden section presented to him by Luca, who calls it Divine proportione.

Very known are the drawings of Leonardo in the divine proportion by Luca so I avoided to be reported.

\section{Acknowledgements}

I would like to thank the two reviewers for their valuable comments and suggestions to improve the quality of my paper.

\section{REFERENCES}

Abattouy, M. (2006). The Arabic transformation of mechanics: The birth of science of weights. Foundation for Science Technology and Civilisation, 615, 1-25

Abattouy, M., Jurgen, R., \& Weinig, P. (2001) Transmission as transformation: The translation movements in the Medieval East and West in a comparative perspective. Science in Context, 14, 1-12. doi:10.1017/S0269889701000011

Archimedes (1558). Archimedis opera non nulla a Federico Commandino Urbinate nuper in latinum conversa et commentariis illustrata. Apud Paulum Manutium, Aldi F. Venetiis

Archimedes (2002). On the equilibrium of planes. In T. L. Heath (Ed.),

${ }^{57}$ da Vinci, Ms K, f. 49r; see also Codex Forster I, folia. 1-40.
The works of Archimedes (pp 189-220). New York: Dover.

Aristotle (1853). On the definition and division of principles. In: O. F. P. Owen (Ed.), The organon, Or logical treatises, of Aristotle (pp. 263-266). London: Bohn H G.

Aristotle (1949). Aristotle's prior and posterior analytics. A revised text with introduction and commentary. Oxford: The Oxford University Press.

Aristotle (1955a). De caelo. The Tech Classics Archive of M.I.T

Aristotle (1955b). Mechanical problems. In: W. S. Hett (Ed.), Aristotle. Minor works. Cambridge: William Heinemann.

Aristotle (1963). Minor works. Heinemann, Cambridge, London: The Harvard University Press.

Aristotle (1984). The complete works of Aristotle. Princeton: The Princeton University Press.

Aristotle (1996). The principles of nature-physics. Oxford: The Oxford University Press.

Aristotle (1999). Physics. Oxford: The Oxford University Press.

Bagni, G. T., \& D'Amore, B. (2007). Leonardo e la matematica. In: I. Marazzani (Ed.), La matematica e la sua didattica (pp. 3-7). Bologna: Pitagora.

Bellucci, G. B. (1598). Nuoua Inventione di fabricar Fortezze, di varie Forme in qualunque sito di piano, di monte, in acqua, con diuersi disegni, et un trattato del modo, che si ha da osseruare in esse, con le sue misure, et ordine di levar lepiante, tanto in fortezze reali, quanto non reali. Venezia: Roberto Meietti.

Biagioli, M. (2003). Galileo e Derrida: Il libro della natura e la logica del supplemento. In Rinascimento ser (pp. 205-232). Firenze: Olschki.

Brown, E. J. (1967-1968). The scientia de ponderibus in the later Middle Ages. Ph.D. Dissertation, Madison: University of Winscosin .

Busard, H. L. L. (2005). Introduction to the text. Campanus of Novara and Euclid's elements I. Stuttgart: Franz Steiner Verlag.

Capecchi, D. (2011). Weight as active or passive principle in the Latin and Arabic scientia de ponderibus. Organon, 43, 29-58

Capecchi, D. (2012). The history of virtual work laws. Basel: Springer. doi:10.1007/978-88-470-2056-6

Capecchi, D, \& Pisano, R. (2007). Torricelli e la teoria dei baricentri come fondamento della statica. Physis, XLIV, 1-29

Capecchi, D., \& Pisano, R. (2008). La meccanica in Italia nei primi anni del Cinquecento. Il contributo di Niccolò Tartaglia. In Proceedings of XXV SISFA Congress (pp. C17.1-C17.6). Milano: University of Milano.

Capecchi, D., \& Pisano, R. (2010a). Scienza e tecnica nell'architettura del Rinascimento. Roma: CISU.

Capecchi, D., \& Pisano, R. (2010b). Reflections on Torricelli's principle in mechanics. Organon, 42, 81-98.

Capecchi, D., \& Pisano, R. (2013). Tartaglia's science of weights. The Mechanics in XVI century. Dordrecht: Springer

Cartelon, H. (1975). Does Aristotle have a mechanics? In Barnes et al. (Eds.), Articles on Aristotle. Vol. I: Science. London: Duckworth.

Clagett, M. (1959). The science of mechanics in the Middle Ages. Madison: The University of Wisconsin Press.

Clagett, M. (1964-1984). Archimedes in the Middle Ages, MadisonPhiladelphia, memoirs of the American Philosophical Society. Oxford: The Clarendon University Press.

Clagett, M., \& Moody, E. (1960). The medieval science of weights. Scentia de ponderibus. Madison: The University of Wisconsin Press.

Comandino, F. (1565). Federici commandini vrbinatis liber de centro gravitatis solidorum. Bononiae: Ex Officina Alexandri Benacii.

Comandino, F. (1575). De gli elementi di Euclide libri quindici. Con gli scholii antichi. Tradotti prima in lingua latina da m. Federico Commandino da Vrbino, \& con commentarij illustrati, et hora di ordine delli istesso trasportati nella nostra vulgare, et da lui riueduti in Vrbino: appresso Domenico Frisolino In Vrbino: in casa di Federico Commandino.

da Vinci, L. (1940). I libri di meccanica nella ricostruzione ordinata di Arturo Uccelli preceduti da una introduzione critica e da un esame delle fonti. Milano: Hoepli.

dal Monte, G. (1581). Le Meccaniche dell'Illustrissimo Sig. Guido Ubaldo dè Marchesi del Monte, tradotto in volgare dal Sig. Filippo 
Pigafetta. Venezia: Evangelista Deuchino.

dal Monte, G. (1588). In duos Archimedis aequeponderantium libros paraphrasis. Pisauri: Hieronymum Concordiam.

de Ridder-Symoens, H. (1992). A history of the university in Europe. Vol. I. Universities in the Middle Ages. Cambridge: The Cambridge University Press.

Dijksterhuis, E. J. (1957). Archimedes. New York: The Humanities Press.

Dijksterhuis, E. J. (1955). The principal works of Simon Stevin, vol. I. Amsterdam: C. V. Swets \& Seitlinger.

Drachmann, A. G. (1967-1968). Archimedes and the science of physics. Centaurus, 12, 1-11. doi:10.1111/j.1600-0498.1968.tb00074.x

Duhem, P. M. (1905-1906). Les origines de la statique 2 vol. Paris: Hermann.

Duhem, P. M. (1906-1913). Etudes sur Léonard de Vinci. Paris: Hermann.

Euclid (1945) The optics of euclid. Trans. by Burton, H. E. Journal of the optical society, 35, 357-372.

Galileo, G. (1890-1909). Le opere di Galileo Galileo: Edizione nazionale sotto gli auspici di sua maestà il re d'Italia. Firenze: Barbera.

Galluzzi, P. (1988). Leonardo da Vinci: Engineer and Architect. Montreal: Montreal Museum of Fine Arts.

Galluzzi, P., \& Torrini, M. (1975-1984). The works of Galileo Galilei's disciples 2 Vols. Correspondence. Firenze: Gunti-Barbera (In Italian).

Gille, B. (1966). Engineers of the renaissance. Cambridge, MA: MIT Press.

Grendler, P. F. (2002). The universities of the Italian renaissance. Baltimora: The Johns Hopkins University Press.

Hall, B. S. (1997). Weapons \& warfare in renaissance Europe. Baltimore: The John's Hopkins University Press.

Harrison, P. (2006). The book of nature and early modern science. In: K. van Berkel, \& A. Vanderjagt (Eds.), Book of nature in early modern and modern history (pp. 1-26). Leuven: Peeters.

Heath, T. L. (2002). The works of Archimedes. New York: Dover Publications Inc.

Hero, A. (1575). Heronis alexandrini spiritalium liber. A federico commandino urbinate, ex graeco, nuper in latinum conversus. Urbini: Frisolino Domenico.

Hero, A. (1893). Les mécaniques ou l'élévateur de Héron d'Alexandrie Arabic text and French translation by Carrà de Vaux. Journal Asiatique, 9, 386-472.

Heron, A. (1900). Herons von Alexandria Mechanik und Katoptrik. In L. Nix, \& W. Schmidt (Eds.), Heronis Alexandrini opera quae supersunt omnia. Leipzig: Teubner.

Heron, A. (1999). Heron alexandrinus mechanica. English translation by Jutta Miller.

http://archimedes.mpiwg-berlin.mpg.de/cgi-bin/toc/toc.cgi

Jesseph, D. M. (2004). Galileo, Hobbes and the book of nature. Perspectives on science, 12, 191-211. doi:10.1162/106361404323119871

Knorr, W. R. (1978-1979). Archimedes and the "elements": Proposal for a revised chronological ordering of the Archimedean corpus. Archive for History of Exact Science, 19, 211-290.

Knorr, W. R. (1985). Archimedes and the pseudo-Euclidean 'catoptrics': Early stages in the ancient geometric theory of mirrors. International Archive on the History Science, 35, 114-115; [1986] 28-105.

Kusukawa, S. (2012). Picturing the book of nature: Image, text and argument in sixteenth-century human anatomy and medical botany. Chicago, IL: The Chicago University Press. doi:10.7208/chicago/9780226465289.001.0001

Locqueneux, R. (2009). Une histoire des idées en physique. Vol. 57. Cahiers d'histoire et de philosophie des sciences. Paris: Vuibert.

Maitte, B. (2003). La géométrie dans les arts décoratifs islamiques. Le Caire: CFCC

Marcacci, F. (2009). Galileo Galilei, sidereus nuncius. Traduzione e commento di giustini PA. Roma: The Lateran University Press.

Marcolongo, R. (1932). La meccanica di Leonardo da Vinci. Napoli: Stabilimento Industrie Editoriali Mendionali. [Id. 1937 (1937). Studi vinciani. Memorie sulla geometria e la meccanica di Leonardo da Vinci. Napoli: Stabilimento Industrie Editoriali Meridionali.
Numbers, R. L. (2006). Reading the book of nature through American lenses. In K. van Berkel, \& A. A. Vanderjagt (Eds.), Book of nature in early modern and modern history (pp. 261-274). Leuven: Peeters.

Van Ophuijsen, J. M. (2005). The two fold action of mind in Aristotle's proto-book of nature. In K, van Berkel, \& A. Vanderjagt (Eds.), Book of nature in antiquity and the Middle Ages (pp. 1-12). Leuven: Peeters.

Othman, A. (1949.) Farabi: La statistique des sciences. (2 ed.). Cairo: Dar al-fikr al-'arabi.

Pacioli, L. (1494). Summa de arithmetica, geometria, proportioni et proporzionalità. Venezia: Paganino de’ Paganini.

Pacioli, L. (1496-1508). De viribus quantitatis. Bibliotheca: University of Bologna.

Pacioli, L. (1509). De divina proportione opera a tutti gli'ingegni perspicaci e curiosi necessaria [...]. Venezia: Paganino de' Paganini.

Pacioli, L. (1509). Euclidis megarensis, philosophi acutissimi mathematicorumque omnium sine controversia principis, opera a Campano interprete fidissimo tra[s]lata.. [...]. Venezia: Paganino de' Paganini.

Pappus, A. (1588). Mathematica collectiones a Federico Commandino urbinate in latinum conversae. Pisauri: Hieronimum concordiam.

Pappus, A. (1970). The Arabic version of the mathematical collection of Pappus Alexandrinus Book VIII. Ph.D. Dissertation. Cambridge: The University of Cambridge Press.

Pedersen, O. (1992). The book of nature. Città del Vaticano: The Vatican Observatory Publications.

Pedretti, C. (1978). Leonardo architetto. Milano: Electa. [Id., 1999 Leonardo. Le macchine, Giunti Editore, Firenze 1999; et refs. on Codex]

Pedretti, C. (1998). Leonardo da Vinci, Il codice arundel 263 nella British library. 2 vols. Firenze: Giunti.

Pisano, R. (2013b). Historical and epistemological reflections on the principle of virtual laws. Submitted to Archive Internationales d'Histoire des Science.

Pisano, R., \& Capecchi, D. (2013b-forthcoming). Conceptual and mathematical structures of mechanical science between 18th and 19th centuries. Almagest, in Press.

Pisano, R. (2007). Brief history of centre of gravity theory. Epistemological notes. In M. Kokowski (Ed.), Proceedings of the 2nd ESHS Congress (pp. 934-941). Krakow.

Pisano, R. (2009a). Continuity and discontinuity. On method in Leonardo da Vinci' mechanics. Organon, 41, 165-182.

Pisano, R. (2009b). Il ruolo della scienza archimedea nei lavori di meccanica di Galilei e di Torricelli. In E. Giannetto, G. Giannini, D. Capecchi, \& R. Pisano (Eds.), Proceedings of XXVI SISFA Congress (pp. 65-74). Rimini: Guaraldi Editore.

Pisano, R. (2009c). On method in Galileo Galilei' mechanics. In H. Hunger (Ed.), Proceedings of ESHS 3rd Conférence (pp. 147-186). Vienna: Austrian Academy of Science.

Pisano, R. (2009d). Galileo Galileo. Riflessioni epistemologiche sulla resistenza dei corpi. In E. Giannetto, G. Giannini, \& M. Toscano (Eds.), Relatività, Quanti Chaos e altre Rivoluzioni della Fisica (61-72). Rimini: Guaraldi Editore.

Pisano, R. (2011). Physics-mathematics relationship. Historical and epistemological notes. In E. Barbin, M. Kronfellner, \& C. Tzanakis (Eds.), European Summer University history and epistemology in mathematics (pp. 457-472). Vienna: Verlag Holzhausen GmbH-Holzhausen Publishing Ltd.

Pisano, R., \& Bussotti, P. (2012). Galileo and Kepler. On theoremata circa centrum gravitates solidorum and mysterium cosmographicum. History Research, 2, 110-145.

Pisano, R., \& Capecchi, D. (2009). Il ruolo della meccanica ne le fortificationi di Buonaiuto Lorini (pp 797-808). Napoli: Cuzzolin Editore.

Pisano, R., \& Capecchi, D. (2010a) Galileo Galilei: Notes on trattato di fortificazione. In A. Altamore, \& G. Antonini (Eds.), Galileo and the Renaissance Scientific Discourse (pp. 28-41). Roma: Edizioni Nuova Cultura.

Pisano, R., \& Capecchi, D. (2010b) On Archimedean roots in Torricelli's mechanics. In S. A. Paipetis, \& M. Ceccarelli (Eds.), The genius of Archimedes. Proceeding of an internal conference (pp. 


\section{R. PISANO}

17-28). Syracuse.

Pisano,R., \& Capecchi, D. (2008). La meccanica in Italia nei primi anni del Cinquecento. Il contributo di Niccolò Tartaglia. In P. Tucci (Ed.), Proceedings of XXV SISFA Congress (pp. C171-C176). Milano. http://www.brera.unimi.it/sisfa/atti/index.html

Pisano, R., \& Capecchi, D. (2009). Il ruolo della meccanica ne Le fortificationi di Buonaiuto Lorini In Cuzzolin (Ed.), 3 Convegno di Storia dell'ingegneria, vol. II (pp. 797-808). Napoli.

Pisano, R., \& Gaudiello, I. (2009). Continuity and discontinuity. An epistemological inquiry based on the use of categories in history of science. Organon, 41, 245-265.

Pisano, R., \& Rougetet, L. (2013-forthcoming). Quelles mathématiques trouve-t-on chez Leonardo da Vinci et chez Luca Pacioli? In press.

Renn, J., Damerow, P. \& McLaughlin, P. (2003). Aristotle, Archimedes, Euclid, and the origin of mechanics: The perspective of historical epistemology. Berlin: The Max Planck Institute for the history of science of Berlin.

Rogers, K. (2005). On the metaphysics of experimental physics. New York: Palgrave Macmillan.

Rose, P. L. (1975). The Italian renaissance of mathematics. Geneve: Droz.
Sarton, G. (1953). Leonardo de Vinci, ingenieur et savant. Paris: Colloques Internationaux.

Schneider, J. H. J. (2011). Philosophy and theology in the Islamic culture: Al-Farabi's de scientiis. Philosophy Study, 1, 41-51.

Tartaglia, N. (1554). La nuova edizione dell'opera Quesiti et inventioni diverse de Nicolo Tartaglia brisciano Riproduzione in facsimile dell'edizione del 1554. In A. Masotti (Ed.), Commentari dell'Ateneo di Brescia. Brescia: Tipografia La Nuova cartografica.

Tartaglia, N. (1565a). Archimedes De insidentibus aqueae, Lib. I et II, in Iordani Opvscvlvm de Ponderositate. Venetia: Apud Curtium Troianum Navò

Tartaglia, N. (1565b). Iordani opvscvlvm de ponderositate, nicolai tartaleae stvdio correctvm novisque figvrisavctvm. Cvm Privilegio Traiano Cvrtio, Venetiis, Apvd Curtivm Troianvm.

Truesdell, C. (1968). Essay in the history of mechanics. New York: Spinger. doi:10.1007/978-3-642-86647-0

Vanderputten, S. (2005). Exploring the book of nature? Human history and natural history in monastic historiography from the Middle Ages. In K. van Berkel, \& A. Vanderjagt (Eds.), Book of Nature in Antiquity and the Middle Ages (pp. 151-166). Leuven: Peeters. 